\title{
Analysis of Profitability through Common Size Profit and Loss Statement
}

\author{
Davendra Kumar Sharma
}

\begin{abstract}
A business cannot exist without profit and an economy cannot exist without sound business. Profits must be something for all to be proud of they should not be suspected. In India, public enterprises utilize such a large proportion of nation's resources that they should run efficiently and contribute to the growth of the economy and welfare of the community. Profit making is seldom the primary objective of public undertakings. The theories of profit propounded by economists from time to time such as 'Risk Theory of Hawley', 'Rent Theory of Walker', 'Uncertainty Bearing Theory of Knight', and 'Dynamic Theory of J.B. Clark', have failed to accord a precise unequivocal meaning to this term. And with the advent of socialistic philosophy which looks at profit from an entirely different angle, the controversy has further depended.

The main objectives of the present research work are to study that how assets and liabilities are managed by State Financial Corporations and how does it affect profitability through common size profit \& Loss. This study will help the Rajasthan Financial Corporations in improving their assets-liabilities management efficiency and hence profitability. The suggested ways and means of practical significance for improving the techniques relating to profitability, capital structure etc. will improve the financial performance and working of the corporations.
\end{abstract}

Keywords: Risk Theory, Rent Theory, Uncertainty Bearing, Dynamic Theory, Capital Structure.

\section{INTRODUCTION}

\section{Profit and Profitability}

Although profit as one of the basic objectives of business has been universally recognised and has also been accepted as a principal measure of business performance, there has been a long controversy as to the word 'profit' among economists, businessmen and accountants. The term 'profit' has not been precisely defined. As pointed out by Smith, "The term 'profit' carries a variety of meanings not only in technical sense but in interpretative sense as well". "Profit is the engine that drives the business enterprise". "Profits are the soul of the business without which it is lifeless. In fact, profits are useful intermediate beacon towards which a firm's capital should be directed".

The word 'ability' means the capacity to earn profits or operating performance. The word 'profitability' may be defined as "the ability of a profit. Profitability is the index of the performance and of the better utilization of the financial resources. The criterion of profits is a common standard of

Revised Manuscript Received on July 22, 2019

Dr. Davendra Kumar Sharma, Associate Professor, S. S. Jain Subodh P G (Autonomous) College, Jaipur. measuring efficiency. It is a general criterion which indicates the overall efficiency combining of all different operations together.

\section{REVIEW OF LITERATURE}

"A business cannot exist without profit and an economy cannot exist without sound business. Profits must be something for all to be proud of they should not be suspected". The principal motivating force behind conducting a business is profit. "Perhaps the most important reason for keeping accounts, as far as the management of the business is concerned, is that the information contained in them provides the means of measuring the progress of the business, of testing its pulse, and of indicating when and where remedial action, if necessary, shall be taken".

The theories of profit propounded by economists from time to time such as 'Risk Theory of Hawley', 'Rent Theory of Walker', 'Uncertainty Bearing Theory of Knight', and 'Dynamic Theory of J.B. Clark', have failed to accord a precise unequivocal meaning to this term. And with the advent of socialistic philosophy which looks at profit from an entirely different angle, the controversy has further depended.

Professor Samualson is of the view that 'profits' are the report-card of the past, the incentive gold star for the future and also the stake for your new venture. Accountants compute profits because profit index is not only a reliable indicator of business activity but also an absolute measure of efficient performance in using productive resources.

Cohen and Robbins observed, "Despite their loose base, profits are probably the most widely used measure of performance. Investors employ it when they evaluate a company, competitors rely upon it for gauging progress; and employees resort to it in wage determination.

'Profitability", this word comprises of two words 'profit' and 'ability'. Kohler defined the profit as amount remaining as balance from revenue after deducting the related costs. According to him in modern times profit is considered under the following two meanings:

(i) Excess of revenue over operating costs, and

(ii) Excess of revenue over operating cost and other deductions.

Published By:

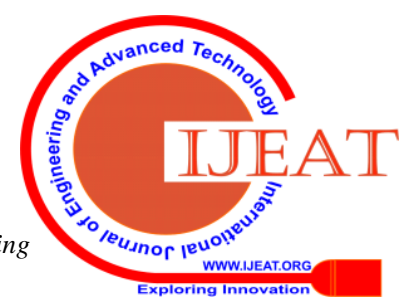


In this context, Ramaswamy also observes, "A Financial Corporation should earn definite percentage on total assets. Profit should be earned from each of activities and each sphere".

While emphasizing the importance of increasing profits in a financial corporation, the views of Lord Latham, are of special significance. He points out that, "if circumstances are favorable, satisfactory profits can conceal inefficiency while in unfavorable circumstances, a proper degree of efficiency may be achieved in spite of an absence of profits".

\section{OBJECTIVES OF THE STUDY}

The main objectives of the present research work are to study that how assets and liabilities are managed by Rajasthan Financial Corporation and how does it affect profitability. Main objectives of the present study are as follows:

- Profitability trend in Rajasthan financial corporation under study over the period of study.

- Study of profitability and its relationship with financial strength.

- To evaluate utility and scope of E-banking and it has been curtained how far it can improve the profitability.

- An effort has been made to provide a framework that may be most suitable for Rajasthan financial corporation in India under the current scenario.

- Research has been concluded by bringing some concrete suggestions in form of model or formula to correlate and profitability which Rajasthan financial corporation may adopt easily.

\section{RESEARCH METHODOLOGY}

The following tools and techniques have been used in the collection, analysis and interpretation of data and information:

(1) Sample Size and Area of the Study: The study covers a period of five years from 2013-14 to 2017-18 of Rajasthan Financial Corporation

(2) Source of Data: The present study is based on secondary data which are used during the study. Data were collected from Annual Reports and Accounts of Rajasthan Financial Corporation for last 5 years.

(3) Type of Research: The research is exploratory in nature and attempts to have a deep insight into the Profitability of the said unit.

(4) Tabulation: After collection of data, consolidated financial statement is prepared in a tabular manner.

(5) Scope of the Study: The scope of the study has been restricted to a critical study of the Rajasthan Financial Corporation. This study is an attempt to bring into focus on the profitability of the Rajasthan Financial Corporation which is useful to know for individuals, for businessmen, for society, etc.

(6) Contribution from the Study: Presently, financial sector is facing competition in the present era of
Liberalization, Privatization and Globalization (LPG). Problem is further aggravated due to entrance of foreign banks which are getting deposit in their countries at a very low rate of interest. In India also, during last few years, savings and capital formation is increased which has increased supply of deposits and at the same time there is a grave need of low rate financing so that businessmen in India can face global competition. As a result of it, rate of interest on deposits as well as on credit is reduced sharply and trend is still continued.

In such a situation, every financial institution is bringing its Initial Public Offer (IPO) for shares and getting capital at low cost as burden of dividend will be quite less compared to rate of interest on deposits if dividend is compared to issue price of share. Financial institutions will be in a position to issue share at higher price only if profitability is high and profitability will be more if there is proper assets and liabilities management.

Thus, in the present circumstances Rajasthan Financial Corporation is left with no choice except increasing profitability by proper assets and liabilities management. So, this subject of research is very important not only for Rajasthan Financial Corporation but also for public at large and Indian Economy which is at thrash root of growth and development.

This study can help the Rajasthan Financial Corporation in improving its profitability. The suggested ways and means of practical significance for improving the techniques relating to profitability, working capital requirements, solvency, capital structure etc, can improve the financial performance and working of the corporation.

(7)Limitations of the Study: An external analyst has to function under various constraints and limitations. Since the analyst has to depend heavily upon published reports and secondary data, one of the limitations lies in the quality of the accounting data. Further, the techniques and tools of investigations have also inherent limitations, e.g. financial data are the mixture of convenience and convention. Lastly, the study is a subject to general human limitations.

\section{RESULTS AND EVALUATION OF PROFITABILITY OF RAJASTHAN FINANCIAL CORPORATION}

To evaluate the profit performance, the profitability of the Rajasthan Financial Corporation has been studied. Common-size profit and loss statement has been prepared.

Common size statement is said to be the miniature of the original and most valuable to an analyst in studying the current financial position and operating results of a business and especially in making comparison between companies in the same industry and with industry standards. The methods of ratio analysis and funds flow analysis have a common limitation that they fail to show the changes that have taken place from year to year

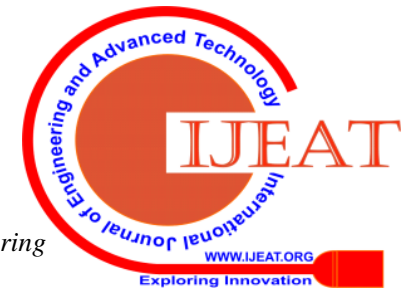


in relation to the total assets, liabilities and capital. This limitation may be eliminated by common size analysis.

In the present study, common-size profit and loss accounts of Rajasthan State Financial Corporation has been prepared for the period under study i.e. from 2013-14 to 2017-18.
The absolute rupee amounts have been expressed in crores of rupees upto two decimal places. To evaluate the profit performance, the profitability of the Rajasthan Financial Corporation has been studied.

Table- II: Profit and Loss Account of Rajasthan Financial Corporation (2013-14 to 2017-18) (Rs. in Crores)

\begin{tabular}{|c|c|c|c|c|c|c|c|c|c|c|}
\hline \multirow[t]{2}{*}{ Particulars } & \multicolumn{2}{|c|}{ 2013-14 } & \multicolumn{2}{|c|}{ 2014-15 } & \multicolumn{2}{|c|}{ 2015-16 } & \multicolumn{2}{|c|}{ 2016-17 } & \multicolumn{2}{|c|}{ 2017-18 } \\
\hline & Amount & $\%$ & Amount & $\%$ & Amount & $\%$ & Amount & $\%$ & Amount & $\%$ \\
\hline \multicolumn{11}{|l|}{ INCOME } \\
\hline $\begin{array}{l}\text { Interest on Loans \& } \\
\text { Advances }\end{array}$ & 107.99 & & 111.99 & & 133.92 & & 166.55 & & 199.11 & \\
\hline \multirow[t]{2}{*}{ Less : Rebate Allowed } & - & & - & & - & & - & & 92.03 & \\
\hline & 107.99 & 92.94 & 111.99 & 90.08 & 133.92 & 94.56 & 166.55 & 94.32 & 107.08 & 90.61 \\
\hline Other Operating Income & 7.48 & 6.44 & 11.64 & 9.36 & 6.86 & 4.84 & 9.22 & 5.22 & 8.44 & 7.14 \\
\hline Bad Debts Recovered & 0.72 & 0.62 & 0.69 & 0.56 & 0.85 & 0.60 & 0.82 & 0.46 & 2.66 & 2.25 \\
\hline Total & 116.19 & 100.00 & 124.32 & $\begin{array}{c}100.0 \\
0\end{array}$ & 141.63 & $\begin{array}{c}100.0 \\
0 \\
\end{array}$ & 176.59 & $\begin{array}{c}100.0 \\
0\end{array}$ & 118.18 & $\begin{array}{c}100.0 \\
0\end{array}$ \\
\hline \multicolumn{11}{|l|}{ EXPENDITURE } \\
\hline $\begin{array}{l}\text { Interest and Financial } \\
\text { Charges }\end{array}$ & 81.64 & 70.26 & 73.74 & 59.31 & 71.38 & 50.39 & 73.00 & 41.34 & 73.12 & 61.87 \\
\hline Personnel \& Adm. Expenses & 19.29 & 16.60 & 23.22 & 18.68 & 25.03 & 17.67 & 24.74 & 14.01 & 26.31 & 22.26 \\
\hline Other Expenses & 13.80 & 11.88 & 22.17 & 17.83 & 38.32 & 27.06 & 63.05 & 35.70 & 3.17 & 2.68 \\
\hline $\begin{array}{l}\text { Depreciation \& } \\
\text { Amortization }\end{array}$ & 0.29 & 0.25 & 0.42 & 0.34 & 0.95 & 0.67 & 1.26 & 0.71 & 0.65 & 0.55 \\
\hline Bad Debts Written Off & 0.01 & 0.01 & 0 & & 0 & & 2.98 & 1.69 & 3.59 & 3.04 \\
\hline $\begin{array}{l}\text { OPERATING PROFIT } \\
\text { /LOSS) Before Provision } \\
\text { and Tax }\end{array}$ & 1.16 & 1.00 & 4.78 & 3.84 & 4.95 & 4.21 & 11.55 & 6.55 & 11.35 & 9.60 \\
\hline Total & 116.19 & 100.00 & 124.32 & $\begin{array}{c}100.0 \\
0\end{array}$ & 141.63 & $\begin{array}{c}100.0 \\
0\end{array}$ & 176.59 & $\begin{array}{c}100.0 \\
0\end{array}$ & 118.18 & $\begin{array}{c}100.0 \\
0\end{array}$ \\
\hline \multicolumn{11}{|l|}{ Less : } \\
\hline $\begin{array}{l}\text { Provision for Bad \& } \\
\text { Doubtful Debts }\end{array}$ & 3.00 & & 0.10 & & 0.25 & & 0.60 & & 0.60 & \\
\hline Provision for Taxation & 0.25 & & 0 & & 0 & & 0.50 & & 0.10 & \\
\hline Fridge Benefit Tax & 0 & & 0 & & 0 & & 0.09 & & 0.10 & \\
\hline Wealth Tax & 0.01 & & 0.01 & & 0.01 & & 0.01 & & 0.02 & \\
\hline & 3.26 & 2.81 & 0.11 & 0.09 & 0.26 & 0.18 & 1.20 & 0.68 & 0.82 & 0.69 \\
\hline Net Profit/(Loss) & 0.80 & 0.69 & 1.76 & 1.42 & 4.68 & 3.30 & 10.32 & 5.86 & 10.54 & 8.92 \\
\hline Earnings Per Share & 1.38 & & 2.71 & & 7.20 & & 13.70 & & 13.34 & \\
\hline
\end{tabular}

Source: Annual Reports and accounts of Rajasthan Financial Corporation during the period under study from 2013-14 to 2017-18.

The common-size profit and loss account of Rajasthan Financial Corporation during the period of study from 2013-14 to 2017-18 has been exhibited in above Table. The operating income of Rajasthan Financial Corporation registered an increasing trend throughout the entire period except the last year of the study. It was Rs. 116.19 crore in the year 2013-14 and then started increasing. Reaching at Rs. 124.32 crore in the year 2014-15, it increased up to Rs.
141.63 crore in the year 2015-16 which reached upto Rs. 176.59 crore in 2016-17. Finally, it decreased and came down to Rs. 118.18 crore in the last financial year of the study period i.e. 2017-18.

The interest on laons and advances has the major contribution in total income. In 2013-14, it was 92.94 percent which decreased to 90.08 in 


\section{Analysis of Profitability through Common Size Profit and Loss Statement}

2014-15 but increased to 94.56 percent in 2015-16, then slightly declined to 94.32 percent in 2016-17 and finally with some decreased due to rebate allowed, it reached to 90.61 percent in 2017-18. Other operating income and bad debts recovered were the other contributors to income of RFC. In expenditure, interest and financial charges made majorcontribution. In 2013-14, interest and financial charges were 70.26 percent which decreased to 59.31 percent in 2014-15, 50.39 percent in 2015-16 and 41.34 percent in 2016-17, then it increased to 61.87 percentin the final year of the study.

The profit before taxes of the RajasthanFinancial Corporation was positive throughout the study period andincreased continuously except 2017-18. It was Rs. 1.16 crore means onepercent of operating income in 2013-14 which increased sharply to Rs. 4.78 crore i.e. 3.84 percent in 2014-15, Rs. 4.95 crore means 4.21 percent in 2015-16 and reached upto Rs. 11.55 crore or 6.55 percent in 2016-17, then decrease a bit and resulted as Rs. 11.35 crore which was 9.60 percent of operating income in the year 2017-18. The net profit of the Rajasthan Financial Corporation increased continuously throughout the period under study. It was Rs. 0.80 crore i.e. 0.69 percent in 2013-14 which increased to Rs. 1.76 crore means 1.42 percent in $2014-15$, Rs. 4.68 crore or 3.30 percent in $2015-16$, Rs. 10.35 crore which was 5.86 percent in 2014-15 and reached up to Rs. 10.54 crore means 8.92 percent of operating income in the last yearof the study period i.e. 2017-18. It shows that the profitability of the Corporation was increasing slowly but steadily during the period under study.

\section{CONCLUSION}

Conclusively, by analyzing the profit and loss account of the Rajasthan Financial Corporation, following points have been visualized:

(1) The operating income of Rajasthan Financial Corporation registered an increasing trend throughout the entire period except the last year of the study. This is a good symbol of corporation.

(2) The interest on loans and advances was the main contributor in operating income of RFC. It shows the sound position of corporation. It showed a fluctuating trend throughout the period under study.

(3) The total operating expenses for Rajasthan Financial Corporation also showed a fluctuating trend throughout the study period. It shows the flexibility of expenses.

(4) The operating profit (before taxes) was always positive in Rajasthan Financial Corporation throughout the study period. It means RFC was in profitable condition during the study period.

(5) The net profit of the Rajasthan Financial Corporation increased continuously throughout the period under study except in the year 2017-18. It shows sound position of the corporation.

\section{REFERENCES}

1. Argenti John, Corporate Planning- A Practical Guide, (London: George Allan and Unwin Limited, 2005), p.34.

2. Bion B. Howard Millor Upton, Introduction to Business Finance, McGraw Hill, New York, 2011, p.150.

3. Duck, R.E.V. and Jervis, F.R.J., Management Accounting, George G. Harrap and Company Ltd., U.S.A., 2009, p.78.

4. Fourth Conference of Asian and Pacific Accountants, New Delhi, 2001, p.143.

5. Gole, V.L., Analysis and Interpretation of Financial Statements, Botterworth, Sydney, 2002, p.85.

6. Harold Bierman, Jr. and Allan R. Drebin, Managerial Accounting: An Introduction, The Macmillan Company, New York, 2002, p. 225

7. Harper, W.M., Management Accounting, Macdonald and Evans, London, 1988 , p. 11.

8. Murphy M.E., Managerial Accounting, (New York: D. Van Nostrand Company, New Delhi: Affiliated East-West Press, Indian Reprint, 2002), p.87.

9. Om Prakash, The Theory and Working of State Corporations, Orient Longman, London, 2011, p.301.

10. Prasanna Chandra, Financial Management Theory and Practice, Tata McGraw-Hill Publishing Company Limited, New Delhi, 2009, p.125.

11. Sharma Davendra and Srivastava Anubha (2017), "Comparative Profitability Analysis Between Rajasthan Financial Corporation and Delhi Financial Corporation", Journal of Management Outlook, Journal of Research Development Association, India, Vol. 6(2), pp.39-50.

12. Sharma Dr. D K, (2011), "Financial Analysis through Common-Size Balance Sheet - A Case Study of Raymond Ltd.” Proficient International Refereed Journal of Management, India, Vol. 3(7), pp.24-29.

13. Singh, V.S., Public Enterprises in India Financial Policy and Performance of Government Companies, Deep and Deep Publications, New Delhi, 2004, p.149.

14. Singhal Richa (2016), Profitability Analysis through Common Size profit and loss of Delhi Financial Corporation, Journal of Business \& Management, Department of Business Administration, University of Rajasthan, Jaipur, Vol. 01, No. 01, pp.100-106.

15. Singhal Richa (2016), Profitability Analysis of Rajasthan Financial Corporation, INSPIRA- Journal of Commerce, Economics \& Computer Science, Vol.02, No.04, Oct-Dec,2016, pp.77-82.

16. Smith R.L., Management through Accounting, (New Jersey: Prentice Hall, Inc., 1962), p.90.

17. Van Horne, J.C.: Financial Management and Policy, (New Delhi Prentice Hall of India, 2011), p.726 